\title{
PENGARUH BIAYA PRODUKSI TERHADAP PENETAPAN HARGA JUAL KUE KERING - BAKPIA PADA UD. NEW TWEETY DESA TAKERAN RT 04 RW 01 KECAMATAN TAKERAN KABUPATEN MAGETAN
}

\author{
Heniy Undaryani Dewi \\ Pendidikan Ekonomi FKIP UNIVERSITAS PGRI MADIUN \\ undaryaniheni@gmail.com
}

\begin{abstract}
This study aims to determine Production Costs incurred by the company UD. New Tweety-Magetan, and to determine the effect on the production cost selling price determination pastries bakpia-Bakpia At UD. New Tweety. The sampling technique in this study using purposive sampling technique that uses the samples for 4 of the last period started the company UD. New Tweety-Magetan founded. Data collection method used is observation, interview and documentation methods. Analysis of the data used to use Descriptive Statistics analysis using Simple Linear Regression Analysis, The results showed that the positive influence between the production cost of the determination of the selling price. This is shown by a simple linear regression equation $Y=91.880+0.708 X$ that could mean that in any rise in the cost of production is always followed by a rise in selling prices, as well as vice versa in any reduction in production costs always follow gathering decrease in selling prices. In this study the effect of production cost and the selling price by $65.7 \%$ and $34.3 \%$ influenced by conditions or other variables such as market demand and consumer tastes will be Pastries Bakpia.
\end{abstract}

Keywords: Production Costs, Selling Prices

\begin{abstract}
Abstrak
Penelitian ini bertujuan untuk mengetahui Biaya Produksi yang dikeluarkan Oleh Perusahaan UD. New Tweety-Magetan, dan untuk mengetahui pengaruh biaya produksi terhadap penetapan harga jual Kue Kering-Bakpia Pada UD. New Tweety. Teknik pengambilan sampel dalam penelitian ini menggunakan teknik sampling purposive yang menggunakan sampel selama 4 periode terakhir dari mulai perusahaan UD. New TweetyMagetan di dirikan. Metode pengumpulan data yang digunakan adalah metode observasi, metode wawancara dan metode dokumentasi. Analisis data yang digunakan menggunakan Analisis Statistik Deskriptif dengan menggunakan Analisis Regresi Linier Sederhana. Hasil penelitian menunjukkan bahwa adanya pengaruh yang positif antara biaya produksi terhadap penetapan harga jual. Hal ini di tunjukan dengan persamaan regresi linear sederhana $Y=91,880+0,708 \mathrm{X}$ yang dapat di artikan bahwa dalam setiap kenaikan dalam biaya produksi selalu diikuti dengan kenaikan harga jual, begitupun juga sebaliknya dalam setiap penurunan biaya produksi selalu diikuti pula penurunan harga jual. Dalam penelitian ini pengaruh biaya produksi dan harga jual sebesar $65,7 \%$ dan 34,3\% dipengaruhi oleh kondisi ataupun variabel lain seperti permintaan pasar dan selera konsumen akan kue keringbakpia.
\end{abstract}

Kata Kunci: Biaya Produksi, Harga Jual 


\section{PENDAHULUAN}

Dalam perusahaan manufaktur biaya produksi dan harga jual merupakan suatu hal yang amat penting dalam suatu perusahaan. Sebelum membahas mengenai biaya produksi dan harga jual Daljono (2005: 15) menyatakan bahwa biaya yang terjadi di perusahaan dapat dikelompokan berdasar keterkaitannya (hubungannya) dengan produk.Biaya ini sifatnya melekat pada produk.

Dalam pembuatan produk terdapat dua kelompok biaya: biaya produksi dan biaya non produksi. Biaya produksi merupakan biaya-biaya yang dikeluarkan dalam pengolahan bahan baku menjadi produk (Mulyadi, 2005: 16).

Dengan demikian biaya produksi dihitung untuk jangka waktu tertentu untuk menghasilkan informasi biaya produksi persatuan produk. Dalam penetapan harga jual produk, biaya produksi per unit merupakan salah satu informasi yang dipertimbangkan disamping informasi biaya lain serta informasi nonbiaya (Mulyadi, 2009: 65).

Dalam biaya produksi suatu produk penetapan harga jual suatu produk merupakan hal yang sangat penting pagi manajemen perusahaan. Menurut Kamaruddin Ahmad (2005: 171) faktor-faktor yang mempengaruhi harga jual diantaranya laba dan tujuan lain, situasi pasar, biaya produksi dan operasi. Walaupun terdapat banyak aspek yang dipertimbangkan oleh perusahaan dalam menentukan harga jual produk, seringkali faktor biaya dijadikan titik tolak dalam penetapan harga jual produk (Rudianto, 2013: 127). Dalam penentapan harga jual suatu produk perusahaan harus mempertimbangkan dan memperhitungkan laba atau keuntungan yang diperoleh hal ini sesuai dengan pendapat yang telah dikemukakan oleh Mulyadi.

Pada perusahaan manufaktur ini menggunakan suatu pendekatan yang cenderung condong pada pasar atau berbasis pada biaya yang diambil sebagai titik awal untuk pengambilan keputusan dalam penentuan harga jual. Di dalam perusahaan haruslah mempertimbangkan pelanggan, kompetitor dan biaya, bukan hanya memperhatikan di salah satu pihak saja agar nantinya perusahaan tidak kalah saing dengan perusahaan lain yang memproduksi produk sejenis. Menurut Batistian Bustami dan Nurlela (2006: 178 ) "harga jual merupakan pembebanan biaya atas dasar nilai jual masing-masing produk. Terdapat hubungan secara langsung antara biaya dan harga jual, dimana harga jual dari suatu produk lebih banyak ditentukan oleh biaya produksi”.

"Penentuan harga jual produk atau jasa merupakan suatu jenis pengambilan keputusan manajemen yang penting. Bagi manajemen penentuan harga jual produk atau jasa bukan hanya merupakan kebijaksanaan di bidang pemasaran atau bidang keuangan, melainkan merupakan kebijakan yang berkaitan dengan seluruh aspek kegiatan perusahaan" (Abdul Halim dan Bambang Supomo 2009: 97)

Pendapat yang telah dikemukakan oleh Abdul Halim dan Bambang Supomo, dalam jangka waktu tertentu jika suatu perusahaan tidak menetapkan harga jualnya dengan tepat maka perusahaan akan mengalami kerugian yang akan menganggu perkembangan perusahaan, sehingga dapat mengalami kerugian dan kebangkrutan karena ketidakseimbangan antara biaya produksi dan hargajualnya.

\section{METODE PENELITIAN}

Penelitian ini dilaksanakan di UD NEW TWEETY Desa Takeran RT 04 RW 01 Kecamatan Takeran Kabupaten Magetan. Adapun waktu yang diperlukan dalam penelitian ini adalah selama 6 bulan, terhitung sejak bulan Maret 2016 sampai dengan Agustus 2016. 
Desain penelitian yang digunakan dalam penelitian ini menggunakan deskriptif kuantitatif. Penelitian deskriptif kuantitatif dalam penelitian ini adalah merupakan suatu proses pemecaham masalah yang dilakukan untuk memperoleh suatu informasi dalam suatu penelitian yang dilakukan dengan berdasarkan fakta-fakta yang nyata. Pada penelitian ini menggunakan hubungan sebab akibat (kausal) karena hubungan variabel terhadap obyek yang diteliti lebih bersifat sebab akibat (kausal) yaitu dimana ada pengaruh antara variabel bebas (Biaya Produksi) dengan variabel terikat (Harga Jual).

Populasi dalam penelitian ini adalah seluruh biaya produksi yang di keluarkan oleh perusahaan UD. New Tweety-Magetan dari mulai perusahaan berdiri sampai dengan sekarang untuk sampel peneliti mengunakan empat tahun terakhirnya itu selama 48 bulan karena selama empat tahun terakhir perusahaan dianggap mengalami perkembangan yang cukup pesat. Dalam penelitian ini menggunakan teknik pengambilan sampel Sampling Purposive.

Teknik pengumpulan data yang di gunakan dalam penelitian ini adalah menggunakan wawancara yaitu segala sesuatu yang berkaitan dengan bahan baku, tenaga kerja dan biaya overhead pabrik yang secara langsung ditanyakan kepada pemilik perusahaan ataupun kepada karyawan dari perusahaan UD. New Tweety. Observasi yang di mana peneliti mengamati secara langsung dari dekat pada perusahaan untuk mendapatkan data mengenai proses produksi. Dokumentasi digunakan peneliti untuk memperoleh data mengenai biaya produksi yang telah di keluarkan oleh perusahaan selama empat periode terakhirnya itu 48 bulan sebagai pendukung penelitian dari pengaruh biaya produksi terhadap penetapan harga jual. Indikator dari harga jual menurut Kamarudin Ahmad (2005: 171) menyatakan bahwa terdapat tiga faktor yang merupakan ringkasan berbagai faktor yang mempengaruhi harga jual yaitu : 1) Laba dan tujuan lain: faktor lain selain pasar dan biaya. 2) Situasi pasar: meliputi konsumen, sifat biaya dan operasi. 3) Biaya produksi dan operasi :Yaitu biaya yang di keluarkan untuk membuat barang (produk) dan biaya produk tersebut bisa sampai ke tangan konsumen.

Menurut Bastian Bustami dan Nurlela (2006: 10) "Biaya Produksi adalah biaya yang digunakan dalam proses produksi yang terdiri dari bahan baku langsung, tenaga kerja langsung dan biaya overhead pabrik".

Untuk uji hipotesis di dalamnya menggunakan teknik analisis regresi linear sederhana menggunakan koefisien determinasi dan uji t. Koefisien determinasi digunakan untuk menguji pengaruh antara variabel satu dengan yang lain. Variabel yang dimaksud adalah variabel independen yaitu biaya produksi $(\mathrm{X})$ dan variabel dependen yaitu harga jual (Y). Sedangkan untuk lebih memperkuat data digunakanlah uji $\mathrm{t}$, untuk mengetahui apakah variabel independen (X) secara individu mempunyai pengaruh yang signifikanterhadapvariabeldependen(Y).

\section{HASIL DAN PEMBAHASAN \\ Gambaran Umum Tentang UD. New Tweety-Magetan}

Pada tanggal 23 April 2000, UD. New Tweety membentuk industri rumahan magetan dan bertekat untuk menjadikan kota magetan sebagai pusat belanja oleh-oleh. UD. New Tweety lebih fokus untuk melayani pembuatan kue kering-bakpia. Perusahaan yang didirikan oleh Bapak Samiyo ini membuat kue bakpia pada acara atau hari tertentu seperti pada saat banyaknya pesanan untuk Hari Raya Idul Fitri dan acara hajatan.

Dengan berkembangnya usaha ini dilingkungan Ds. Takeran RT 04 RW 01 Kec. Takeran, Magetan, Bapak Samiyo sebagai pemilik perusahaan semakin mengembang- 
kan industry UD. New Tweety dengan memproduksi beraneka ragam kue kering dan dengan 18 karyawan yang bekerja setiap hari untuk membuat kue kering dan bakpia.

\section{Variabel Biaya Produksi pada UD. New Tweety-Magetan}

Deskriptif biaya produksi pada perusahaan UD. New Tweety- Magetan dapat di katakan bahwa biaya produksi dengan jumlah data $(\mathrm{N})$ sebanyak 48 mempunyai deskripsi data sebagai berikut (a) nilai ratarata hitung (mean) 203,77; (b) median sebesar 207,00; (c) modus sebesar 181; (d) standart deviasi sebesar 27,400; (e) nilai minimum sebesar 147; (f) nilai maximum sebesar 256; (g) sum sebesar 9781 .

\section{Variabel Harga Jual pada UD. New Tweety-Magetan}

Harga Jual dengan jumlah data $(\mathrm{N})$ sebanyak 48 mempunyai deskripsi data sebagai berikut (a) nilai rata-rata hitung (mean) 236,23; (b) median sebesar 236,00; (c) modus sebesar 241; (d) standart deviasi sebesar 23,940; (e) nilai minimum sebesar 199; (f) nilai maximum sebesar 300; (g) sum sebesar 11339.

\section{Hasil Uji Hipotesis}

\section{Uji Analisis Regresi Liniear Sederhana}

Dari hasil perhitungan regresi linear sederhana yang telah dilakukan dapat diperoleh persamaan $\mathrm{Y}=91,880+0,708 \mathrm{X}$ yang artinya jika variabel biaya produksi (X) dinaikan sebesar 1\% maka variabel harga jual akan bertambah $0,708 \%$. Dengan nilai konstanta 91,880 menunjukan bahwa biaya produksi pada UD. New Tweety akan konstan apabila biaya produksi (X) sama dengan nol (tidak ada), dengan asumsi faktor lain tetap atau tidak berubah nilainya.

\section{Koefisien Determinasi (R-Square)}

Dari hasil perhitungan diperoleh hasil $\mathrm{R}$
Square sebesar 0,657 atau sebesar 65,7\% dimana sisanya yang sebesar $34,3 \%$ dipengarui oleh berbagai kondisi ataupun variabel lain seperti permintaan pasar dan selera konsumen akan kue kering-bakpia, hal ini menunjukan bahwa adanya hubungan antara variabel (x) yaitu biaya produksi terhadap variabel (y) yaitu harga jual.

\section{Uji t}

Dari hasil analisis regresi atau uji $\mathrm{t}$ tersebut maka diperoleh persamaan antara biaya produksi (x) terhadap harga jual (y) diperoleh $t_{\text {hitung }}$ sebesar 9,394 sedangkan $t_{\text {tabel }}$ sebesar 1,678. Maka dapat di ketahui bahwa $t_{\text {hitung }}=9,394>t_{\text {tabel }}=1,678$ sedangkan sig 0,000 yang di mana kurang dari 0,05 berarah positif berarti terdapat adanya pengaruh antara biaya produksi terhadap harga jual sebesar $65,7 \%$ di perusahaan UD. New Tweety-Magetan.

\section{PENUTUP}

\section{Simpulan}

Berdasarkan dari penlitian yang telah di lakukan oleh penulis pada perusahaan UD. New Tweety dan pengolahan data pada bab IV mengenai hasil penelitian, maka dapat disimpulkan dari hasil penelitian tentang "Pengaruh Biaya Produksi Terhadap Penetapan Harga Jual Kue Kering-Bakpia pada UD. New Tweety", sebagai berikut :

1. Biaya yang di keluarkan oleh perusahaan UD. New Tweety untuk proses produksinya pada penelitian ini menggunakan Biaya Bahan Baku, Biaya Tenaga Kerja dan Biaya Overhead Pabrik.

2. Dari hasil penelitian dan pembahasan mengenai pengaruh biaya produksi terhadap harga jual pada perusahaan UD. New Tweety maka dapat di tarik kesimpulan bahwa biaya produksi memiliki pengaruh terhadap penetapan harga jual yaitu sebesar $65,7 \%$ dan sisanya yaitu sebesar $34,3 \%$ dipengaruhi oleh 
varibel lain. Di sini terbukti melalui :

a. Regresi Linier Sederhana

Dari hasil perhitungan regresi linear sederhana yang telah dilakukan dapat diperoleh persamaan $\mathrm{Y}=91,880$ $+0,708 \mathrm{X}$ yang artinya jika variabel biaya produksi (X) dinaikan sebesar 1\% maka variabel harga jual akan bertambah 0,708\%. Dengan nilai konstanta 91,880 menunjukan bahwa biaya produksi pada UD. New Tweety akan konstan apabila biaya produksi (X) sama dengan nol (tidak ada), dengan asumsi faktor lain tetap atau tidak berubah nilainya.

b. Koefisien Determinasi $\left(r^{2}\right)$

Dari hasil perhitungan diperoleh hasil $r_{\text {hitung }} 0,657>r_{\text {tabel }} 0,361$ berarti ada hubungan antara biaya produksi terhadap penetapan harga jual di UD. New Tweety-Magetan.

c. Ujit

Dari hasil perhitungan diperoleh $t_{\text {hitung }}=9,394>t_{\text {tabel }}=1,678$ berarti ada pengaruh antara biaya produksi terhadap penetapan harga jual di UD. New Tweety-Magetan.

\section{Saran}

Dari kesimpulan dan hasil penelitian yang telah tertera di atas, maka penulis mencoba untuk menyampaikan saran yang mungkin dapat bermanfaat dan bisa menjadi masukan bagi pihak perusahaan UD. New Tweety. Adapun saran-saran tersebut diantaranya :

1. Bagi Perusahaan UD. New Tweety

Sebaiknya untuk perusahaan lebih memperhatikan lagi dalam pencatatan biaya produksi yang dikeluarkan karena biaya produksi merupakan faktor penting dalam penetapan harga jual suatu produk yang diproduksinya.

\section{Bagi Peneliti}

Dari hasil penelitian yang telah dilakukan bahwa biaya produksi sangat berpengaruh terhadap penetapan harga jual. Kepada peneliti selanjutnya jika ingin meneliti mengenai harga jual diharapkan bisa untuk meneliti faktor lain selain biaya produksi yang mempengaruhi dalam penetapan harga jual seperti halnya harga pokok, penjualan produk, minat dari konsumen dan laba yang di inginkan oleh perusahaan dll.

\section{DAFTAR PUSTAKA}

Abdul Halim dan Bambang Supomo. 2009. Akuntansi Manajemen. Yogyakarta: BPFE-Yogyakarta.

AhmadKamarudin. 2005. Akuntansi Manajemen: Dasar-dasar Konsep Biaya dan Pengambilan Keputusan. Jakarta: PT Raja Grafindo Persada.

Bustami Bastian dan Nurlela. 2006. Akuntansi Biaya: Kajian Teori dan Aplikasi. Yogyakarta: Graha Ilmu.

Daljono. 2005. Akuntansi Biaya: Penentuan Harga Pokok dan Pengendalian. Semarang: Badan Penerbit Universitas Diponegoro Semarang.

Mulyadi. 2005. Akuntansi Biaya: Edisi ke-5. Yogyakarta: Akademi Manajemen Perusahaan YKPN. 2009. Akuntansi Biaya: Edisi ke-5. Yogyakarta: Unit Penerbit dan Percetakan Sekolah Tinggi Ilmu Manajemen YKPN.

Rudianto. 2013. Akuntansi Manajemen: Informasi Untuk Pengambilan Keputusan Strategis. Jakarta: Erlangga. 